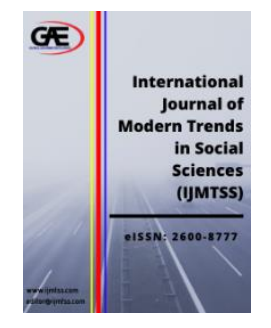

\author{
INTERNATIONAL JOURNAL OF \\ MODERN TRENDS IN \\ SOCIAL SCIENCES \\ (IJMTSS) \\ www.ijmtss.com
}

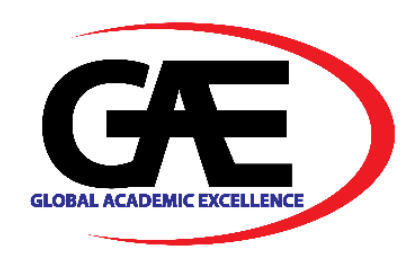

\title{
ACCEPTANCE OF GOOD AGRICULTURAL PRACTICES (GAP) AMONG INDEPENDENT OIL PALM SMALLHOLDERS IN MALAYSIA
} \author{
Tan Say Peng 5 \\ 1 Malaysian Palm Oil Board, Malaysia \\ Email: nurhanani@mpob.gov.my \\ 2 Malaysian Palm Oil Board, Malaysia \\ Email: nazirah@mpob.gov.my \\ 3 Malaysian Palm Oil Board, Malaysia \\ Email: arfan@mpob.gov.my \\ $4 \quad$ Malaysian Palm Oil Board, Malaysia \\ Email: parthiban@mpob.gov.my \\ $5 \quad$ Malaysian Palm Oil Board, Malaysia \\ Email: saypeng@mpob.gov.my \\ * Corresponding Author
}

Nur Hanani Mansor ${ }^{*}$, Nazirah Che Jaafar ${ }^{2}$, Mohamad Arfan Johari ${ }^{3}$, Parthiban Kannan ${ }^{4}$,

\section{Article Info:}

\section{Article history:}

Received date: 11.04 .2021

Revised date: 27.04 .2021

Accepted date: 01.06.2021

Published date: 10.06 .2021

\section{To cite this document:}

Mansor, N. H., Che Jaafar, N., Johari, M. A., Kannan, P., \& Tan, S. P. (2021). Acceptance Of Good Agricultural Practices (GAP) Among Independent Oil Palm Smallholders in Malaysia. International Journal of Modern Trends in Social Sciences, 4 (16), 01-12.

DOI: $10.35631 / \mathrm{IJMTSS.416001}$
Abstract:

Several oil palm sustainable certification schemes have been introduced in Malaysia such as MPOB Codes of Good Agricultural Practices (MPOB CoGAP) Certification, Roundtable on Sustainable Palm Oil (RSPO) certification, and Malaysia Sustainable Palm Oil (MSPO) Certification. All these certifications have been successfully accepted in many of the oil palm estates except the ISH. There is a big challenge to certify the Malaysian ISH because they are lack farm management practice. Therefore, Malaysian Palm Oil Board (MPOB) has introduced the individual sustainable certification to the ISH, which is known as Good Agricultural Practice (GAP) certification. This paper's main objectives are to identify the GAP acceptance level (compliant, partial-compliant, and non-compliant) recommended by MPOB and determine the factors affecting GAP certification acceptance among the ISH in Malaysia. This study was conducted in all states in Malaysia, and the data were collected from a total of 400 respondents selected through the Proportionate Random Sampling Method. The results showed that 58\% of the ISH partially comply by receiving the GAP certificate. while only $26 \%$ fulfilled the requirements, thus eligible for GAP certification. Two factors that significantly influenced the GAP compliance among the ISH were the respondents' education level and the age of palm oil plantation. The results of 


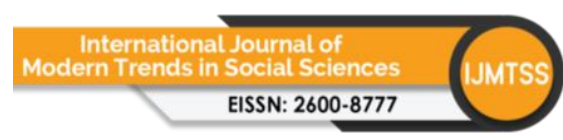

Volume 4 Issue 16 (June 2021) PP. 01-12

DOI 10.35631/IJMTSS.416001

This work is licensed under $\underline{\text { CC BY 4.0 }}$ this study indicated that GAP on fertiliser application and record-keeping were adopted by the ISH and significantly affecting their compliant level of MPOB GAP Certification among ISH.

Keywords:

Oil Palm, GAP, Sustainability, Smallholders, Acceptance

\section{Introduction}

Good Agriculture Practices (GAP) is a collection of principles in the production and the postproduction process at the farm to produce safe and healthy food while considering the aspects of the economy, social, and sustainability of the environment (FAO, 2016). Thus, in order to ensure the sustainability of this industry, Good Agriculture Practice (GAP) has been introduced as a resource management system in the sustainable agriculture production. According to The Department of Agriculture (2018), GAP can increase farm's productivity and produce safe and quality food by taking into account the welfare, safety and health of the workers and preserving the environment. Hence, the productivity of oil palm will be higher if the crop properly managed using best management practice or good agriculture practice (Donough et al, 2009)

Despite the Roundtable on Sustainable Palm Oil (RSPO) in striving to create a more sustainable palm oil industry, its overly restrictive system was deemed impractical for key players such as the smallholders including Malaysia to readily adopt the recommended practices (Corley, 2018; Hutabarat et al, 2019). With this realisation, the MSPO as well as its close ally the Indonesian Sustainable Palm Oil (ISPO), were developed in order to provide equal opportunity to the smallest of farmers to be a part of the more lucrative market of certified sustainable palm oil (CSPO) production.

There is a big challenge to certify the Malaysian ISH due to their various backgrounds, scattered farms, and low GAP practices. According to the MPOB (2019) report, only $10 \%$ of ISH follow acceptable agricultural practices recommended by MPOB. Furthermore, the information on ISH's acceptance level on GAP certification and factors affecting them to comply with GAP requirements are still lacking.

In 2010, MPOB implemented the RSPO Certification for the Malaysian ISH, but it was unsuccessful as the ISH was not adopted the GAP as required by the certification. The certification is a failure is because of the lack of GAP knowledge among the ISH. Study by Nur et al. (2016), showed that adoption of GAP practices among 400 smallholders was only 26\%. This was the biggest challenge for the smallholders. Most of the ISH cultivated their oil palm plantation based on their experience and knowledge inherited from the previous generation. In addition to lack of knowledge, financial constraints among the ISH also affect GAP's adoption.

Adopting the GAP is the basis for increasing productivity, while it is also part of the requirement for all sustainable palm oil certification in the world. Therefore, to continue producing sustainable palm oil in the smallholders' sector, MPOB has taken the initiative to embark a step from the basic level by introducing the GAP Certification to the individual ISH.

Therefore, the main objectives of this study are to identify the GAP acceptance level (compliant, partial-compliant, and non-compliant) as recommended by MPOB and to 


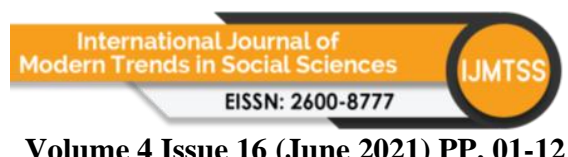

Volume 4 Issue 16 (June 2021) PP. 01-12

DOI 10.35631/IJMTSS.416001

determine the factors affecting GAP certification acceptance among the ISH in Malaysia such as farm size, age, and status of ISH either full or part-time smallholders.

The findings can be used by policymakers to strategies necessary training for the ISH to enhance their acceptance level on GAP practice, and at the same time, increasing numbers of ISH comply with GAP principles and criteria.

\section{Literature Review}

Malaysia is committed to produce sustainable palm oil from all palm oil producer including independent smallholders (ISH). To advance the industry's commitment towards sustainability, the Malaysian Sustainable Palm Oil (MSPO) certification was made mandatory embedded as a national policy (A. Parveev et al, 2019). With it becoming effective from 1 January 2020, it is anticipated that demand for certified sustainable palm oil (CSPO) will soar.

As of December 2019, a total of 3,643,798.92 hectares (62\%) of the oil palm area in Malaysia has been certified under MSPO Certification. From this number, the area of ISH who has been certified is 99,633 hectares, which are about $10 \%$ of the total area of independent smallholder (MSPOTRACE, 2020). The certifications prove that sustainable palm oil certifications have been successfully implemented in many oil palm plantations but not for the ISH farm.

In Malaysia, smallholders in the oil palm supply chain divided into two main categories; independent smallholders and organised smallholders. Independent smallholders are individual farmers who own or lease 40.46 ha or less of an oil palm smallholding and manage the holding themselves or employ workers. The second category of smallholder is the organised smallholders, which are managed by government agencies. As of December 2018, there were a total of 255615 independent smallholders in Malaysia with a total area of 994022 ha, which accounted for 17\% of the total oil palm planted area of 5.85 million hectares (Kushairi et al, 2019).

Senawi et al (2019) stated that to help the ISH be certified, MPOB has set up a Sustainable Palm Oil Cluster (SPOC). The objective of SPOC is to gather the ISH for efficient management to enhance their FFB productivity and increase the income of smallholders. This SPOC will be monitored by MPOB extension officers known as TUNAS (Tunjuk Ajar Nasihat Sawit). The essential components of SPOC are sustainable palm oil certification and the establishment of cooperatives for oil palm smallholders.

The Good Agricultural Practices (GAP) is one of the principles and criteria (P\&C) in the certification of MSPO (P\&C Number 6) and RSPO (P\&C Number 4). GAP's standard operating procedures include maintaining soil fertility, controlling and minimising soil erosion, maintaining adequate surface soil moisture, controlling groundwater quality, and practising integrated pest management (MSPO, 2013 and RSPO, 2007).

Under the MPOB GAP certification program, smallholders must carry 27 GAP criteria listed in Table 1. There are three levels of practices in MPOB GAP Certification, namely 1) compulsory practices, 2) required practices, and 3) encouraged practices. There were three categories of acceptance, namely: (i) compliant and qualified to get MPOB GAP certificate, (ii) partially compliant and needed to make improvements, and (iii) non-compliant and not eligible for the MPOB GAP certificate. 
These three practices cover 27 GAP and are divided into eight main categories of oil palm management. The TUNAS Officers (Tunjuk Ajar Nasihat Sawit) will make an audit at the ISH farm, evaluate and recommend the qualification for awarding the GAP certificate. ISH is complied or qualified to get the MPOB GAP certificate if they practice all the 23 compulsory and required GAP practice. If the ISH did not do at least one of the 21 required GAP practices, they would consider partially comply. For the ISH who do not do any one (1) out of two (2) compulsory practice, they are not eligible to get the MPOB GAP certificate until they are replanting.

Table 1: Gap Criteria For MPOB GAP Certification

\begin{tabular}{|c|c|c|c|}
\hline No. & Category & & GAP \\
\hline \multirow{6}{*}{1} & \multirow{6}{*}{ Land Preparation } & i. & $\begin{array}{l}\text { Construct of terraces/platforms for hilly terrain with } \\
\text { slopes ranging from } 6 \text { to } 25 \text { degrees }\end{array}$ \\
\hline & & ii. & $\begin{array}{l}\text { Using triangular planting system or two-row planting } \\
\text { system }\end{array}$ \\
\hline & & iii. & $\begin{array}{l}\text { Ensuring the palm density based on soil type } \\
\text { - } \quad \text { Inland/alluvium }-148 \text { palms/hectare } \\
\text { - } \quad \text { Peat }-160 \text { palms/ hectare }\end{array}$ \\
\hline & & iv. & $\begin{array}{l}\text { Preparing and maintaining the farm road and harvesting } \\
\text { path for FFB transportation. }\end{array}$ \\
\hline & & $\mathrm{v}$. & $\begin{array}{l}\text { Preparing and maintaining plantation and collector drain } \\
\text { in the swamp and peat area to control the soil's water } \\
\text { level. }\end{array}$ \\
\hline & & vi. & $\begin{array}{l}\text { Ensuring optimum water level in peat area to avoid } \\
\text { continuous drying and soil shrinkage }\end{array}$ \\
\hline \multirow{5}{*}{2} & \multirow{5}{*}{$\begin{array}{l}\text { Fertiliser } \\
\text { Application }\end{array}$} & vii. & $\begin{array}{l}\text { Applying fertiliser using compounds fertiliser based on } \\
\text { recommendation } 6.9 \mathrm{~kg} / \mathrm{ha} / \text { year }\end{array}$ \\
\hline & & viii. & $\begin{array}{l}\text { Applying fertiliser surrounding the oil palm base for the } \\
\text { young palm or on the pruned frond heap for the matured } \\
\text { palm }\end{array}$ \\
\hline & & ix. & $\begin{array}{l}\text { Ensuring rounds of fertiliser application or frequency of } \\
\text { fertiliser application } 2 \text { to } 3 \text { times per year }\end{array}$ \\
\hline & & $\mathrm{X}$. & Using fertiliser within one month after it was received \\
\hline & & & $\begin{array}{l}\text { Ensuring the oil palm does not show any signs of } \\
\text { essential nutrient deficiency }\end{array}$ \\
\hline \multirow{2}{*}{3} & \multirow{2}{*}{ Pruning } & xii. & $\begin{array}{l}\text { Maintaining sufficient green fronds for each palm } \\
\text { according to the age of the palm }\end{array}$ \\
\hline & & xiii. & $\begin{array}{l}\text { Arranging the pruned fronds in between the rows in the } \\
\text { flat area and parallel to contours in the hilly area. }\end{array}$ \\
\hline \multirow{6}{*}{4} & \multirow{6}{*}{ Harvesting } & xiv. & Obtaining the optimal yield based on the palm age \\
\hline & & $\mathrm{XV}$. & Ensuring the harvesting cycle done in between 7-14 days \\
\hline & & xvi. & Harvesting only the ripe FFB \\
\hline & & xvii. & Ensuring the stalk is cut short less than $5 \mathrm{~cm}$ \\
\hline & & xviii. & Collecting all the loose fruits \\
\hline & & xix. & $\begin{array}{l}\text { Sending the FFB and loose fruits together to the FFB } \\
\text { traders or mills within } 24 \text { hours }\end{array}$ \\
\hline
\end{tabular}


Volume 4 Issue 16 (June 2021) PP. 01-12

DOI 10.35631/IJMTSS.416001

\begin{tabular}{|c|c|c|c|}
\hline \multirow{2}{*}{5} & \multirow{2}{*}{$\begin{array}{l}\text { Pest and Disease } \\
\text { Control }\end{array}$} & & $\begin{array}{l}\text { Ensuring that no oil palm trees show the sign of pest } \\
\text { attack }\end{array}$ \\
\hline & & xxi. & $\begin{array}{l}\text { Ensuring no oil palm demonstrates the sign of } \\
\text { Ganoderma infection }\end{array}$ \\
\hline \multirow{3}{*}{6} & \multirow{3}{*}{ Weed Control } & xxii. & $\begin{array}{l}\text { Ensuring no epiphytic or parasitic plants on the oil palm } \\
\text { stems }\end{array}$ \\
\hline & & xxiii. & $\begin{array}{l}\text { Ensuring the surroundings of oil palm is free from weed, } \\
\text { and only soft weeds are maintained. }\end{array}$ \\
\hline & & xxiv. & Practicing an appropriate crop and livestock integration \\
\hline \multirow[b]{2}{*}{7} & \multirow{2}{*}{$\begin{array}{c}\text { Soil } \\
\text { Conservation }\end{array}$} & xxv. & Maintaining of soft weeds cover \\
\hline & & xxvi. & The building of silt pit \\
\hline
\end{tabular}

Note: compulsory practices (i to ii), required practices (iii to xxii), and encouraged practices (xxiii to xxvi)

\section{Methodology}

This study used quantitative methods involving a population of ISH in every state in Malaysia who have been audited with MPOB GAP certification as of December 2013. A total of 1,718 ISH's farm has been visited for MPOB GAP Certification. The proportionate random sampling method was used to determine the number of samples from each state. The sample size calculation was 400 respondents based on the formula by Krejcie and Morgan (1970). The breakdown of the respondent's interview in each state is shown in Table 2. Data collection was conducted through face-to-face interviews by distributing questionnaires and observing the smallholders' farm through the audit checklist of the MPOB GAP certification checklist. The data was analysed using SPSS version 20.0 software.

Table 2: Number Of Independent Smallholder Interview According To State

\begin{tabular}{|c|l|c|c|}
\hline No. & \multicolumn{1}{|c|}{ State } & $\begin{array}{c}\text { Number of } \\
\text { Independent } \\
\text { Smallholders }\end{array}$ & $\begin{array}{c}\text { Number of } \\
\text { Respondents }\end{array}$ \\
\hline 1 & Kedah & 43 & 10 \\
\hline 2 & Pulau Pinang & 17 & 4 \\
\hline 3 & Perak & 305 & 71 \\
\hline 4 & Selangor & 172 & 40 \\
\hline 5 & Negeri Sembilan & 39 & 9 \\
\hline 6 & Melaka & 17 & 4 \\
\hline 7 & Johor & 584 & 136 \\
\hline 8 & Pahang & 82 & 19 \\
\hline 9 & Terengganu & 21 & 2 \\
\hline 10 & Kelantan & 9 & 62 \\
\hline 12 & Sabah & 266 & 38 \\
\hline 13 & Sarawak & 163 & $\mathbf{4 0 0}$ \\
\hline \multicolumn{2}{|c|}{ Total } & $\mathbf{1 , 7 1 8}$ & \\
\hline
\end{tabular}

\section{Result and Discussion}

\section{Independent Smallholders' Demographic Profile}

Descriptive analysis was used to identify the respondent profiles who are involved in this study. The analysis in Figure $1 a$ showed that $81 \%$ of the respondents were males aged above 60 years 


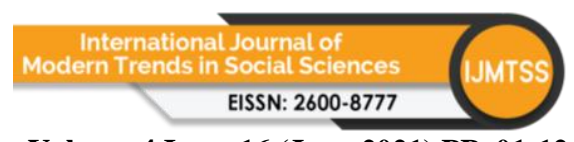

Volume 4 Issue 16 (June 2021) PP. 01-12 DOI 10.35631/IJMTSS.416001

old (39\%) and an average age of 57 years old (Figure $1 b$ ). This finding also similar to the study conducted by Idris (2009) and Zulkifli et al, (2018). The independent smallholders in Malaysia were older people, where 50\% were aged above 50. According to Burton et al, (1999), age farmers influenced the application of technology

The education level of ISH is also one of the factors that have been investigated in this study. It is mainly to determine the acceptance of GAP and new technologies that have been introduced in the oil palm industry. The study by Burton et al, (1999) showed that the farmers' educational background influenced the technology application. The majority of the ISH (46\%) completed secondary school, and only $14 \%$ of them did not receive a formal education (Figure 1c). Some respondents possessed an advanced degree Master or Ph.D., which was $6 \%$ of them. Most of these advanced degree holders were government or private retirees.

Figures $1 d$ and $1 e$ showed that $73 \%$ of the respondents were full-time ISH, while the remaining $27 \%$ were part-time ISH consisting of government officers (12\%), self-employed (9\%), and private officers $(6 \%)$. The full-time ISH livelihood depended mainly on income from their oil palm holdings. The results showed that $43 \%$ and $34 \%$ of the ISH earned RM 1,001 to RM 2,000 and less than RM 1,000 per month, respectively, from their oil palm production (Figure $1 f$ ). This figure is relatively low if compared to their organized counterparts and estates (Azman et al, 2002). Only 5\% of the ISH earned more than RM 4,001 per month.

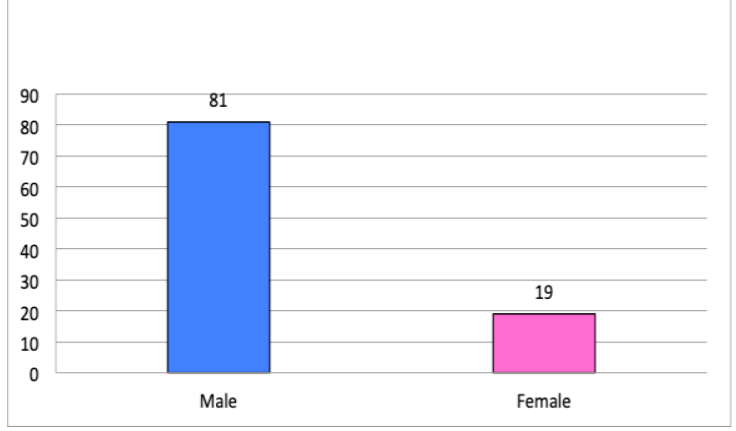

Figure 1a: Gender

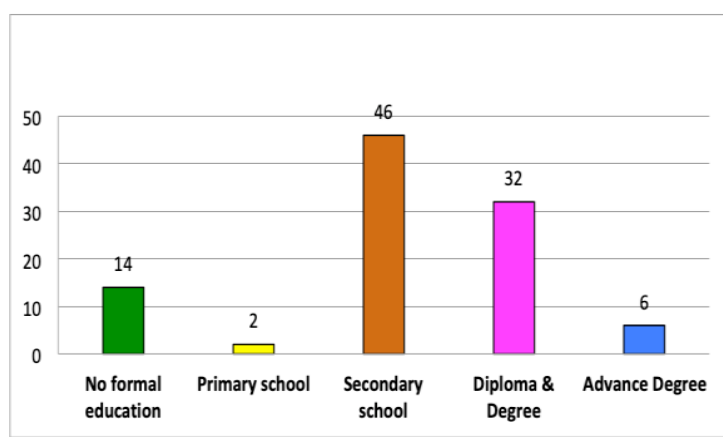

Figure 1c: Level of Education

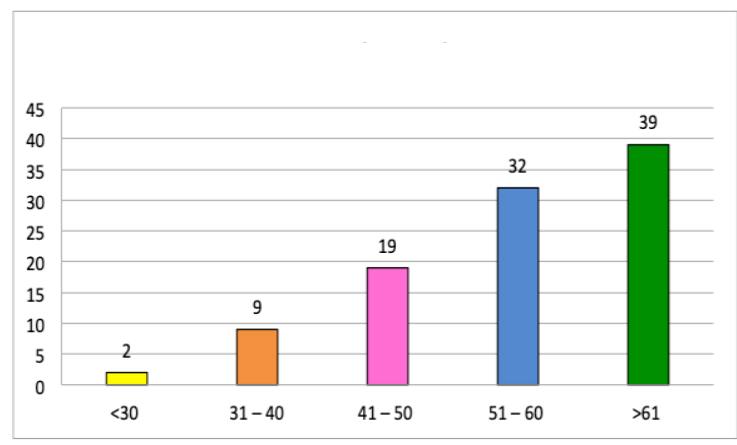

Figure 1b: Age (years)

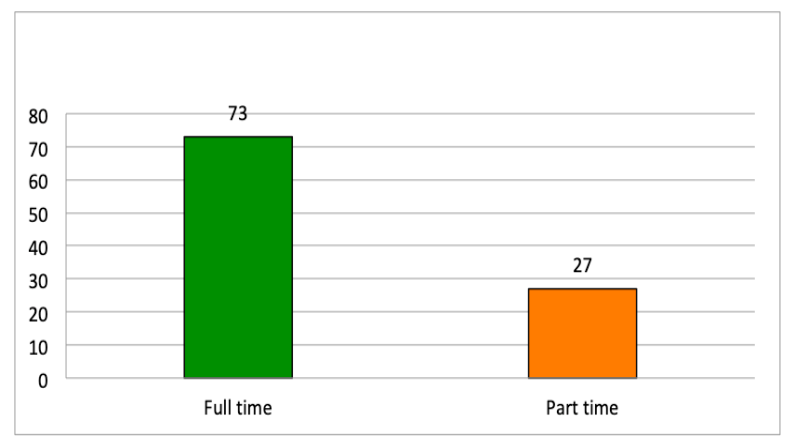

Figure 1d: Level of Independent Smallholders 


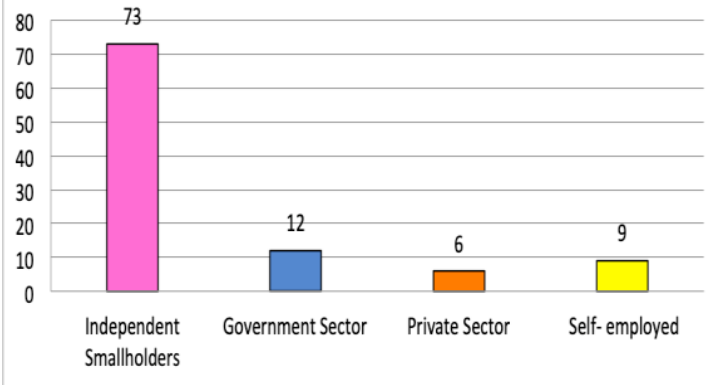

Figure 1e: Other Employment

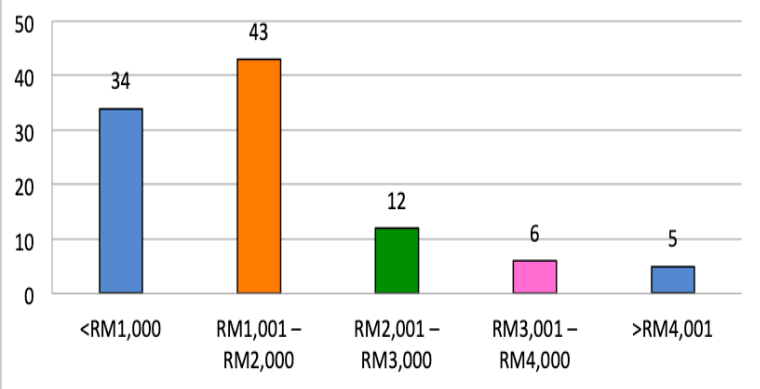

Figure 1f: Income from Oil Palm Farm

\section{Profile of Smallholders' Farm}

The Oil palm ISH is defined as an oil palm grower that owned an oil palm plantation area of 40.46 hectares or less. The average area of ISH's farm ownership in Malaysia is 3.9 hectares. This study showed that the majority of farms owned by ISH were less than 5 hectares $(90 \%)$ (Figure $2 a$ ). Only $1 \%$ of them having a farm size of more than 20 hectares. Figure $2 b$ showed the majority $(65 \%)$ of the respondents having palm age of fewer than five years while the remaining 20\% were between 6 and 10 years, and 15\% were older than 11 years. The production of FFB is essential to assess the performance and productivity of the farm. Half of the respondents $(56 \%)$ were able to produce 10-20 t/ha/yr (Figure 3c).

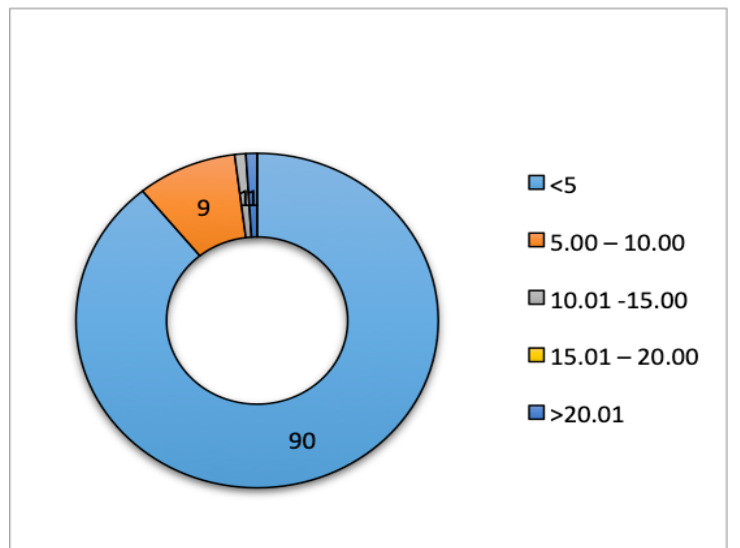

Figure 2a: Farm Size

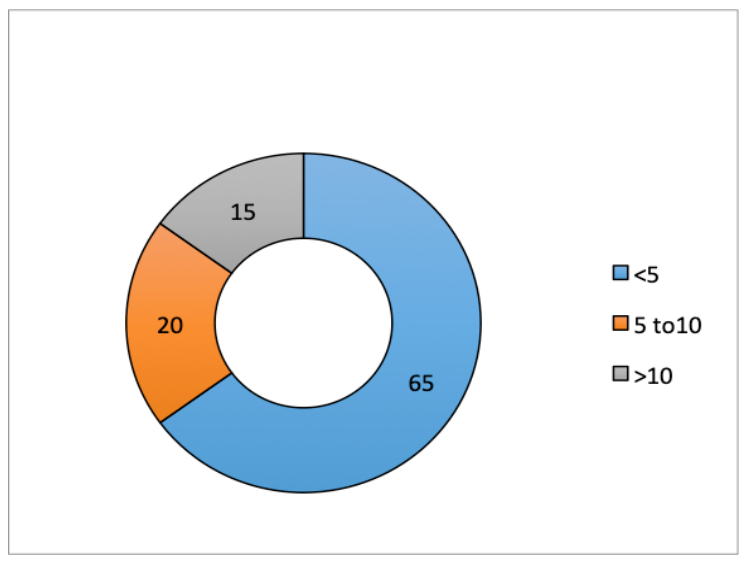

Figure 2b: Palm Age (years)

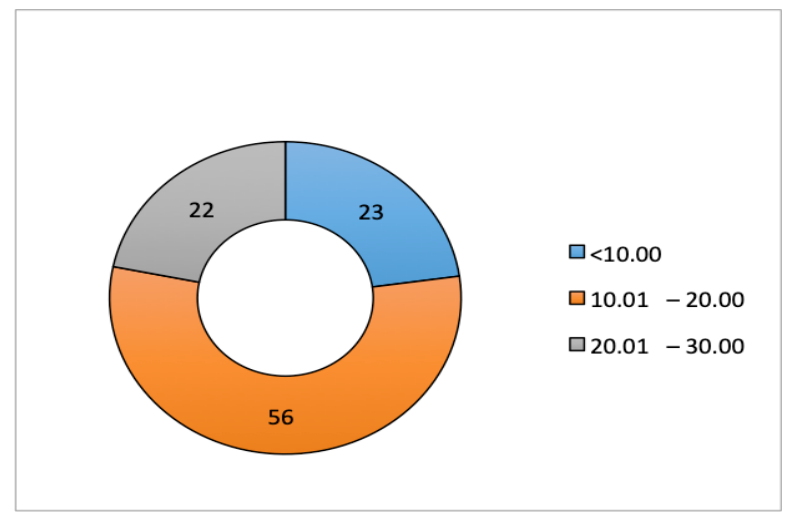

Figure 2c: Yield (tan/ha/year) 




DOI 10.35631/IJMTSS.416001

\section{Acceptance Level of GAP Compliance}

As stated above, the objective of the MPOB GAP Certification implemented by MPOB for the ISH is to increase the productivity of oil palm. Therefore, this study was conducted to focus on the acceptance level of GAP compliance among the ISH to entitle them to get the MPOB GAP certificate. There are three types of GAP practices in the MPOB GAP Certification, specifically compulsory practices, required practices, and encourage practices. Table 3 shows the compliance of GAP by the ISH in Malaysia. There are three categories of acceptance, namely: (i) compliant, (ii) partially compliant, and (iii) non-compliant. ISH is compliant or qualified to get the MPOB GAP certificate if they practice all the 23 compulsory and required GAP practice. If the ISH did not conduct at least one of the 21 required GAP practices, they would consider partially compliant. For the ISH who do not do any one (1) out of two (2) compulsory practice, they are considered not compliant and not eligible to get the MPOB GAP certificate.

Table 3: Frequency Of GAP Compliance

\begin{tabular}{lcc}
\hline Compliance level & Frequency & Percentage (\%) \\
\hline Compliant & 105 & 26 \\
Partially Compliant & 230 & 58 \\
Non-compliant & 65 & 16 \\
\hline
\end{tabular}

The results showed that only $26 \%$ of the respondents have complied with GAP criteria, thus eligible for the MPOB GAP certificate. $58 \%$ of the respondents were only complied partially and need for improvements in the second visit, and $16 \%$ of the respondents have not complied and fails to obtain the certificate. The group of partially compliant ISH has still had the potential to get the GAP certificate if they make corrections or improvements and rectify the noncompliance practices identified in their farms. The remaining $16 \%$ of the smallholders who do not comply are mainly due to significant non-conformance on land preparation practices. The corrective action only can be undertaken when the palm ready to be replanted.

\section{Relationship between Respondents' and Farms' Profile with the Adoption Level of MPOB GAP Certification}

Table 4 shows cross-tabulation analysis and chi-square analysis, which demonstrates the relationship between respondents' and farms' profile with the adoption level of MPOB GAP certification (compliant, partially compliant, or non-compliant). Two factors that significantly influenced the GAP compliance among the ISH were identified. These factors were the age of palm oil plantation and respondents' education level.

Table 4: Relationship Between Respondents' And Farms' Profile With The Acceptance Level Of MPOB GAP Certification

\begin{tabular}{|c|c|c|c|c|c|}
\hline \multirow[b]{2}{*}{$\begin{array}{c}\text { Variable } \\
\text { (Respondent Profile) }\end{array}$} & \multicolumn{3}{|c|}{ Acceptance Level of MPOB GAP Practice } & \multirow{2}{*}{$\begin{array}{l}\text { Chi- } \\
\text { Square } \\
\text { Value } \\
\mathbf{P}<\mathbf{0 . 0 5} \\
\end{array}$} & \multirow[b]{2}{*}{ Statement } \\
\hline & Comply & $\begin{array}{l}\text { Partially } \\
\text { Comply }\end{array}$ & Non-Comply & & \\
\hline $\begin{array}{l}\text { Oil Palm Age (year) } \\
<5 \\
6-10 \\
>11\end{array}$ & $\begin{array}{l}56 \\
28 \\
21\end{array}$ & $\begin{array}{c}171 \\
41 \\
18\end{array}$ & $\begin{array}{l}32 \\
14 \\
19\end{array}$ & 0.00 & Significant \\
\hline $\begin{array}{l}\text { Farm Size (hectare) } \\
<5\end{array}$ & 96 & 208 & 55 & 0.11 & Not Significant \\
\hline
\end{tabular}




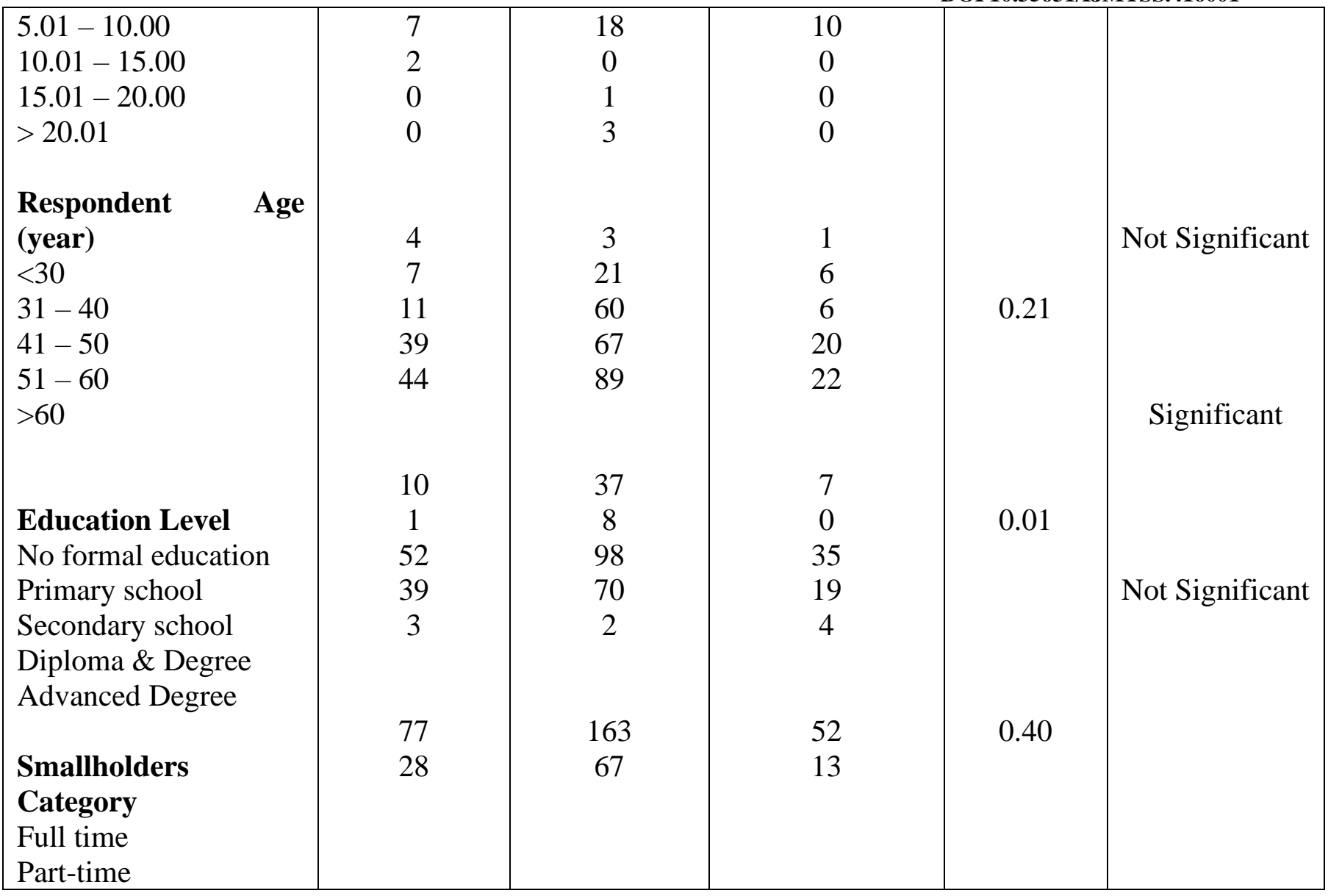

$\mathrm{H}_{0}=$ factors that affect GAP compliance, $\mathrm{H}_{1}=$ factors that do not affect GAP compliance $\mathrm{P} \leq 0.05=$ Accept $\mathrm{H}_{0}, \quad \mathrm{P} \geq 0.05=$ Reject $\mathrm{H}_{0}$

This study's respondents were ISH, who owned an oil palm farm aged between 1 to 20 years old. Results show that 56 smallholders (53.3\%) who complied with GAP certification had an oil palm aged less than five (5) years old. The remaining 28 (26.6\%) and $21(20 \%)$ smallholders complied GAP owned the palms between 6 and 10 and more than 11 years old, respectively. Chi-square analysis showed that the value of $p(0.00)<0.05$. This number showed that the age of oil palm trees significantly affects the acceptance level of GAP compliance. It indicates farmers who owned oil palm farms aged less than five (5) years old practice more GAP than farmers owned older oil palm farm aged.

The education level of smallholders is usually associated with their acceptance level towards new technology. In this study, the education level of respondents was divided into several categories, such as no formal education (does not go to school), primary school, secondary school, college and university (diploma or degree), an advanced degree (Master and Ph.D.). About $185(46 \%)$ respondents were secondary school leavers. Out of this group, 52 smallholders complied with GAP certification, 98 smallholders partially complied, and 35 smallholders have not complied with GAP. The results of the chi-square analysis showed that the respondents' education level had a significant relationship with GAP compliance, as the value of $\mathrm{p}(0.01)<0.05$ smallholders' category/ status 
Relationship between the GAP Level (Low, Medium, and High) and the Acceptance Level of MPOB GAP Certification

Table 5 shows cross-tabulation analysis and chi-square analysis indicating the relationship between the GAP adoption level (low, medium, and high) and the acceptance of MPOB GAP Certification (compliant, partially compliant, or non-compliant). The results of this study indicated that GAP on fertiliser application and record-keeping were adopted by the ISH and significantly affecting their compliant level of MPOB GAP Certification among ISH.

Table 5: Relationship Between The Gap Level (Low, Medium And High) And The Acceptance Level Of MPOB GAP Certification

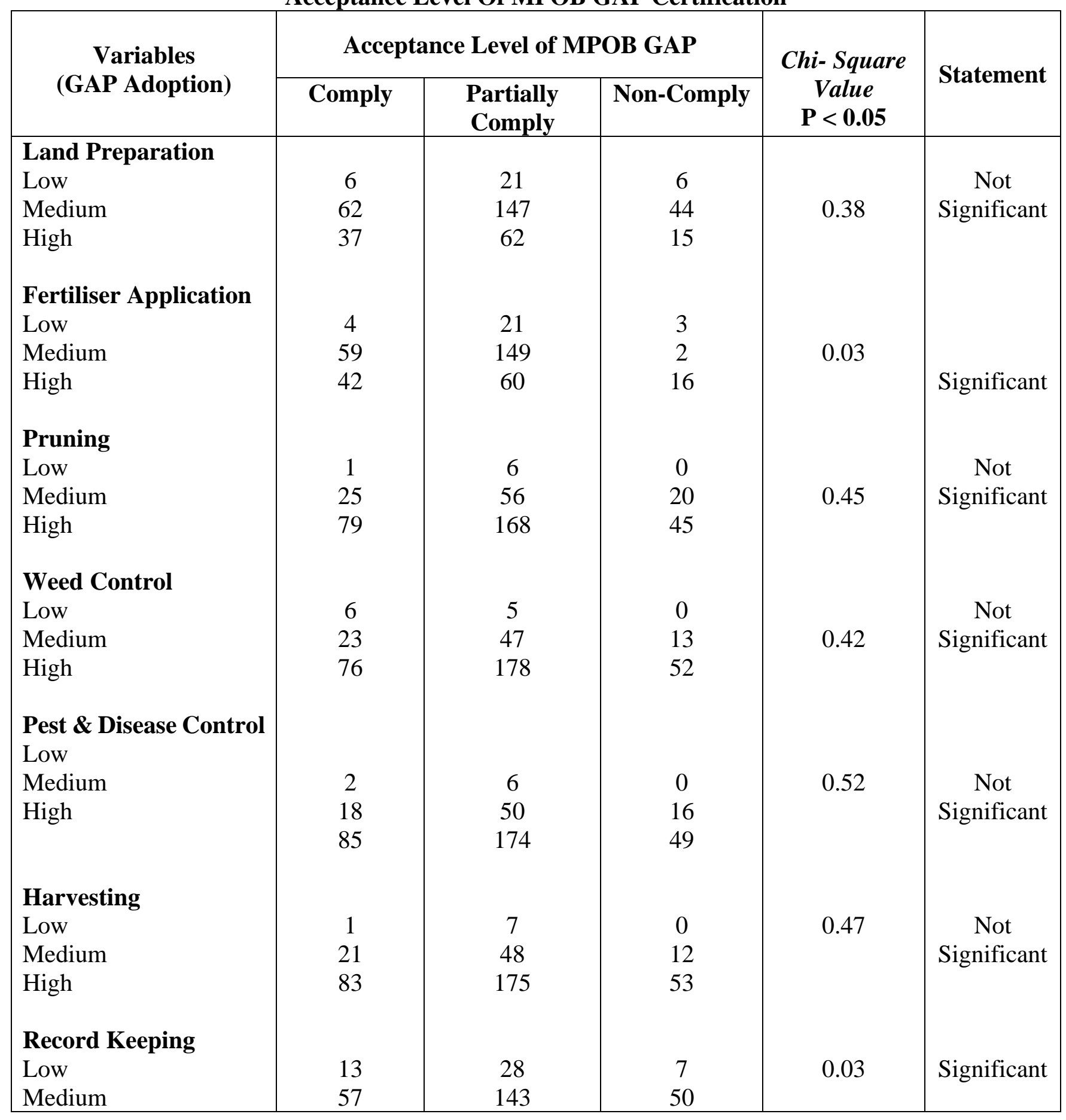




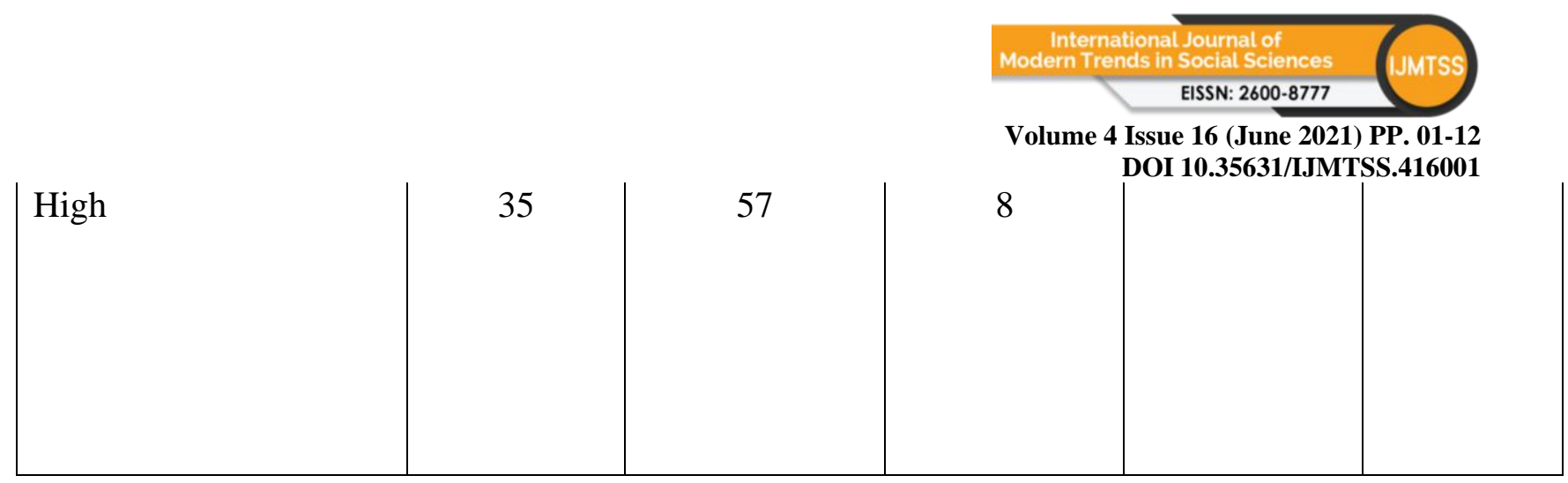

$\mathrm{H}_{0}=$ Factors That Affect the GAP Compliance, $\mathrm{H}_{1}=$ Factors That Do Not Affect the GAP Compliance $\mathrm{P} \leq 0.05=$ Accept $\mathrm{H}_{0}, \mathrm{P} \geq 0.05=$ Reject $\mathrm{H}_{0}$

Fertiliser application is the most critical and expensive practice in oil palm management. Fertilisation could affect the production of FFB. Study by Peng et al (2019) found that ISH have good knowledge of fertiliser nutrient content as well as their application methods, however they lack the knowledge of recognising nutrient deficiency symptoms in the oil palm. The analysis results showed that $118(29.5 \%)$ respondents had a high level of awareness towards fertiliser application practices (Table 5). The chi-square test showed that the fertiliser application practices were significant with the GAP level, where the value of $p(0.03)<0.05$.

Oil palm production encompasses a broad range of activities and high costs. Hence, the smallholders need to possess bookkeeping practise to record all management information, revenue, and expenses related to oil palm management. The analysis results indicated that the majority or 250 respondents $(62.5 \%)$ had a moderate level of awareness regarding record keeping. Out of the 100 (25\%) respondents with a high level of awareness towards the importance of keeping records, only 35 respondents were compiled to GAP record keeping. While 57 respondents potentially complied, and eight respondents were non-complied. The chi-square test showed that record-keeping practice was significant to the GAP level with a value of $\mathrm{p}(0.03)<0.05$.

\section{Conclusion}

The Good Agricultural Practices (GAP) Certification can be used as an indicator to determine the adoption level of acceptable agricultural practices among the ISH. Based on the results showed that $26 \%$ of the ISH have complied with GAP certification and $58 \%$ partially complied, respectively. The remaining $16 \%$ of the ISH did not comply with GAP main requirements, which are using the wrong planting system and do not construct a terrace hilly area. These practices cannot be remedied immediately at the current period of planting. This ISH group was advised to correct their GAP in the planting system and construct terracing in the hilly area when they do their next replanting. Based on demographic respondents and farm profiles, two factors were identified significantly influenced the GAP compliance among ISH. These factors were the education level of respondents and the age of palm. The results of this study indicated that GAP on fertilizer application and recordkeeping were significantly affecting the compliance level of MPOB GAP Certification among ISH.

\section{References}

A. Parveez G.K. Ahmad Parveez, E. Hishamuddin, S.K. Loh, M. Ong-Abdullah, K. Mohamed Salleh, M.N.I.Z. Bidin, S. Sundram, Z.A. Azizul Hasan, Z. Idris (2019) Oil palm economic performance in Malaysia and R\&D progress in 2019. Journal Oil Palm Research, 32 (2020), 159-190.

Azman, I; Arif, S; Mohd Noor, M and Mohd Nasir, A (2002). The cost of FFB production by independent smallholders in Johor, Malaysia. Viva Report. MPOB, Unpublished data. 


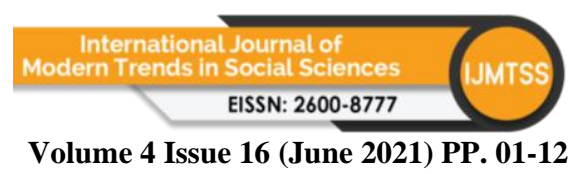

Volume 4 Issue 16 (June 2021) PP. 01-12 DOI 10.35631/IJMTSS.416001

Burton, M., Rigby, D., \& Young, T. (1999). Analysis of the determinants of adoption of organic horticultural techniques in the UK. Journal of Agricultural Economics, 50(1), 47-63.

Corley, R H V (2018). Does the RSPO have a future? Costly criteria inadequate returns. Global Oils \& Fats, Business Magazine, 15(4): 13-18.

Department of Agriculture (2020). Sistem amalan pertanian baik Malaysia. Retrieved from http://www.doa.gov.my/index.php/pages/view/373, [accessed on 18 July 2020].

Donough, C.R., C. Witt and T.H. Fairhurst, (2009). Yield intensification in oil palm plantations through best management practice, Better Crops, Vol. 931/1: 12-14

FAO (2018) - Food and Agriculture Organization (2008). Definition of good agricultural practice. http://www.fao.org/prods/gap, [accessed on 21 January 2018].

Hutabarat, S; Slingerland, M and Dries L (2019). Explaining the 'Certification Gap' fordifferent types of oil palm smallholders in Riau Province, Indonesia. Journal Environment \& Development, 28(3): 253-281.

Idris, O (2009). Enhancing oil palm productivity through participative technology transfer: Malaysian experience. Proceeding of the International Palm Oil Congress 2009, Vol. 1: 337-365.

Krejcie, R. V., \& Morgan, D. W. (1970). Determining sample size for research activities. Educational and Psychological Measurement, 30(3), 607-610.

Kushairi, A; Meilina Ong-Abdullah; Balu Nambiappan; Hishamuddin, E; Vijaya, S; Izuddin, Z B; Razmah, G; Sundram, S and Parveez, G K A (2019). Oil palm economic performance in Malaysia and R\&D progress in 2018. Journal Oil Palm Research. Vol. 31(2): 165-194.

MPOB (2019). Smallholder Factsheet December 2019. Smallholders Development and Research Division, Malaysian Palm Oil Board. Unpublished data.

MSPO (2013). Malaysian Sustainable Palm Oil Standard Part 2 (2013) MS 2503-2:2013. General principles for independent smallholders_ICS: 65.020.20. Department of Standards, Malaysia.

MSPOTRACE (2020). https://mspotrace.org.my/ [accessed on January 2020]

Nur, H M; Nazirah, C J; Ainul, S S; Mohamad, A J; Amran, A; Nursuhan, D; Parthiban, K; Tan, S P; Kahirul, A; Shakir, A; Mohd, K I and Hamdan, A B (2016). Penerimaan Guna Amalan Pertanian Baik (GAP) di kalangan pekebun kecil sawit persendirian di Malaysia. Proceeding of the Palm Oil Smallholders Conference 2016. 169-183.

Peng, T S; Hashim, K; Mansor, N H; Kannan, P; Ariffin, A; Johari, M A and Isnin, K A (2019). Assessment on knowledge on fertiliser management among independent smallholders in Malaysia. Oil Palm Industry Economic Journal 19(2): 1-16.

Roundtable on Sustainable Palm Oil - RSPO (2007). Principles and criteria for sustainable palm oil production. https://rspo.org/resources/certification/rspo-principles-criteriacertification [accessed on February 2018]

Senawi, R; Rahman, N K; Mansor, N and Kuntom, A (2019). Transformation of oil palm independent smallholders through Malaysian Sustainable Palm Oil. Journal Oil Palm Research. Vol. 31(3): 496-507.

Zulkifli, A. M; Sheilyza, M. I. and Kamalrudin, M. S. (2018). Early impact of oil palm replanting and new planting schemes on productivity and field practices of smallholders. Journal of International Academic Research for Multidisciplinary, Vol. 6: 1-12. 